Abstracta Iranica Abstracta Iranica

Revue bibliographique pour le domaine irano-aryen

Volume 30 | 2010

Comptes rendus des publications de 2007

\title{
« Max Planck Institute Afghan family law workshop report ».Yearbook of Islamic and Middle Eastern Law, Vol. 11, N 5, 2007, pp. 397-404.
}

\section{Anicée Van Engeland}

\section{(2) OpenEdition}

Journals

Édition électronique

URL : http://journals.openedition.org/abstractairanica/38161

DOI : 10.4000/abstractairanica.38161

ISSN : 1961-960X

Éditeur :

CNRS (UMR 7528 Mondes iraniens et indiens), Éditions de l'IFRI

Édition imprimée

Date de publication : 8 avril 2010

ISSN : 0240-8910

Référence électronique

Anicée Van Engeland, « « Max Planck Institute Afghan family law workshop report ». Yearbook of Islamic and Middle Eastern Law, Vol. 11, № 5, 2007, pp. 397-404. », Abstracta Iranica [En ligne], Volume $30 \mid$ 2010, document 330, mis en ligne le 08 avril 2010, consulté le 05 octobre 2020. URL : http:// journals.openedition.org/abstractairanica/38161; DOI : https://doi.org/10.4000/abstractairanica. 38161

Ce document a été généré automatiquement le 5 octobre 2020.

Tous droits réservés 


\section{« Max Planck Institute Afghan} family law workshop report ».Yearbook of Islamic and Middle Eastern Law, Vol. 11, N 5,
2007, pp. 397-404.

\section{Anicée Van Engeland}

1 La loi sur le droit de la famille de 1977 est toujours en vigueur mais est largement méconnue par la population. De plus, la coexistence d'un droit codifié avec un droit coutumier non officiel rend difficile le respect et l'application de cette loi de 1977. Le droit de la famille est comme souvent dans les pays qui s'inspirent de la Shari'a un problème majeur pour le respect des droits de la femme. Il est donc important de divulguer la loi et la mettre à portée de tous de manière à réguler ou mettre fin aux mariages d'enfants, aux mariages forcés et à la polygamie, d'encourager l'inscription au registre civil et de faciliter la procédure du divorce pour que les droits des femmes écrits dans la loi de 1977 soient respectés.

\section{INDEX}

Thèmes : 13.2. Afghanistan 


\section{AUTEURS}

\section{ANICÉE VAN ENGELAND}

European University Institute - Florence 